\title{
Roman Novak \\ Ruhr-University, Bochum \\ VALUE-BASED IDEAS OR MATERIAL INTERESTS? AN EXPLANATION OF POLISH GOVERNMENTAL PREFERENCE FORMATION TOWARDS EUROZONE ACCESSION
}

DOI: $10.2478 /$ ppsr-2020-0007

\begin{abstract}
Author
Roman Novak is a research associate at the Chair of International Politics, Ruhr-University Bochum, Germany. He has graduated from the Institute of International Relations of Kyiv National University (Ukraine) with an M.A in International Information and from the Ruhr-University Bochum with an M.A. in Ethics - Economics, Law and Politics. In his PhD project, Roman analyses domestic societal foundations of policy preferences' variation among Central and Eastern European EU members' governments.

ORCID no. 0000-0003-0843-3751

e-mail: roman.novak@rub.de

Abstract

Why did Poland not join the Eurozone despite being integrated economically and dependent on investments and trade with existing Eurozone countries? The reluctance of its government seems puzzling taking into consideration Polish economic exposure to Eurozone countries as well as its commitment to switch to the euro stemming from EU treaties. The Polish governmental position on Eurozone accession demonstrates that monetary integration is not only an economic and legal issue, but it also results from political decisions of individual governments. This paper argues that a complementary understanding of the position of the Polish government on Eurozone accession is possible by looking at domestic ideas and interests. For this aim, the societal approach to governmental preference formation is employed. It focuses on the influence of domestic ideas (value-based collective expectations of voters) and interests (cost-benefit calculations of lobby groups) on governmental positions. In applying the societal approach, this paper has two goals: first, to show that the Polish governments' reluctance to join the Eurozone stems from domestic societal pressures (value-based ideas and material interests) and, second, to specify the conditions for either ideas' or interests' individual bearing on the government's preference.
\end{abstract}

Keywords: Poland, domestic politics, societal approach, Eurozone accession

\section{Introduction}

Poland belongs to the former Warsaw Pact countries that, after the collapse of the Soviet Union, oriented themselves towards Western institutions and started the transition to a market economy. Poland's government managed to implement rapid reforms, which helped to achieve a largely successful structural adjustment (Riedel 2015, p. 194; Beblavy 2007). In 2004, Poland joined the European Union (EU). Accession to the EU, however, does not conclude the process of Poland's European integration. The currency union - the 
last stage of the European Monetary Union (EMU) - is another step which it is obliged to take according to EU treaties. The adoption of the single currency-the euro-is part of the requirement that all countries ${ }^{1}$ are committed to fulfil when they become EU members. However, after an initial inclination to join the Eurozone, the Polish government has refused to do this and indefinitely postponed its accession (Johnson 2008, p. 827).

This paper seeks to bring light to the reasons for delaying monetary integration by this country under scrutiny. The paper is set out in four steps. First, the empirical puzzle and the research question are presented. Second, the theoretical framework, the hypotheses and the operationalisation will be introduced. Third, the case study dealing with the analysis of the variables shaping the governmental preference on Eurozone accession will be conducted. Fourth, empirical findings are aggregated and the viability of the proposed hypotheses is assessed.

\section{The empirical puzzle}

Under the Treaty on the Functioning of the European Union (TFEU), Poland is obliged to join the Eurozone and adopt the euro as its official currency as soon as it meets the Maastricht (convergence) criteria ${ }^{2}$ (EC 2018). Although Poland has demonstrated its ability to comply with basic economic requirements - price stability, long-term interest rates, and the government's financial position (budget deficit percent of GDP, debt-to-GDP ratio) - stipulated by the Maastricht criteria (see Table 1), it continually postpones the Eurozone accession (ECB 2016, p. 111). Reports from the European Commission (EC 2016, p. 88) and the European Central Bank (ECB 2016, p. 186) conclude that laws in Poland do not comply with the requirements for Eurozone accession.

Table 1. Fulfilment of Maastricht criteria

\begin{tabular}{|c|c|c|c|c|c|c|c|}
\hline & & Budget & & Excha & ge rate & Long-term & \\
\hline & rate & $\begin{array}{c}\text { deficit to } \\
\text { GDP }\end{array}$ & GDP ratio & $\begin{array}{l}\text { ERM II } \\
\text { member }\end{array}$ & $\begin{array}{c}\text { Change in } \\
\text { rate }\end{array}$ & $\begin{array}{c}\text { interest } \\
\text { rate }\end{array}$ & of legislation \\
\hline $\begin{array}{l}\text { Reference } \\
\text { values }\end{array}$ & $\begin{array}{l}\text { Max. } \\
0.7 \%\end{array}$ & $\begin{array}{c}\text { Max. } \\
3 \%\end{array}$ & $\begin{array}{c}\text { Max. } \\
60 \%\end{array}$ & $\begin{array}{c}\text { Min. } \\
2 \text { years }\end{array}$ & $\begin{array}{l}\text { Max. } \\
\pm 15 \%\end{array}$ & $\begin{array}{l}\text { Max. } \\
4.0 \%\end{array}$ & Yes \\
\hline Poland & $-0.5 \%$ & $2.6 \%$ & $51.3 \%$ & No & $-7.5 \%$ & $2.9 \%$ & No \\
\hline
\end{tabular}

Source: ECB (2016)

Thus, despite the legal obligation to join the Eurozone (institutionalist argument), key steps to initiate the accession, such as the harmonization of the legal framework with the Eurozone standards or the submission to the Exchange Rate Mechanism II (ERM II), remain under sovereign control of the country (IMF 2015, p. 4). Considering all the ad-

\footnotetext{
1 Denmark and the United Kingdom negotiated opt-out arrangements.

2 The Maastricht criteria (convergence criteria) are a set of macroeconomic indicators which measure price stability, to show inflation is controlled; soundness and sustainability of public finances, through limits on government borrowing and national debt to avoid excessive deficit; exchange-rate stability, through participation in the ERM II for at least two years without strong deviations from the ERM II central rate; long-term interest rates, to assess the durability of the convergence achieved by fulfilling the other criteria (EC, 2018).
} 
vantages and disadvantages of monetary integration is thus ultimately an issue of national preference that might contradict the commitments stemming from EU treaties.

Moreover, as it will be shown below (see Case study), Poland is strongly dependent on exports to and foreign direct investments (FDI) from Eurozone countries. Therefore, it seems reasonable for Poland to join the Eurozone and thereby avoid transactional costs that are an obstacle to substantial economic gains (a neofunctionalist argument). Instead, it continually postpones accession to the Eurozone. Refusal of the Polish government to join the Eurozone seems puzzling in light of Poland's experience of transition from a planned economy to a market economy, accession to the EU and subsequent trade and investment exposure to the Eurozone countries. Based on the aforementioned puzzle, the following research question is formulated: Why did Poland not join the Eurozone despite being dependent on investments and trade with Eurozone countries?

\section{Theoretical framework}

In order to address the research question, this paper follows the societal approach to governmental preference formation developed by Schirm (2011, 2013, 2016, 2018a, 2018b). It incorporates and develops further domestic politics approaches from Taking Preferences Seriously: A Liberal Theory of International Relations (Moravcsik 1997), Varieties of Capitalism (Hall and Soskice 2001) and Historical Institutionalism (Fioretos 2011).

The core assumption of the societal approach is that governments strive to be re-elected and, therefore, are prone to be responsive and accountable to dominant societal influences. Consequently, governmental positions express preferences originating from societal pressures prior to engaging in interstate negotiations (Schirm 2011, p. 50; 2013, p. 690). Contrary to most other authors who employ domestic determinants separately (e.g. Frieden and Rogowski, 1996; Goldstein and Keohane, 1993; Moravcsik, 1997) Schirm includes three explanatory variables in his analysis: value-based ideas, material interests and regulatory institutions ${ }^{3}$.

Schirm (2011, p. 49) defines value-based ideas as "path-dependent and value-based collective expectations" regarding appropriate governmental position on certain policies. Material interests in turn are defined as "material economic considerations of domestic actors which are shaped through the costs and benefits induced by market conditions and expected from policy initiatives" (Schirm 2011, p. 48). Material interests (hereinafter "interests") are expected to change promptly depending on the costs and benefits induced by changing global, regional and national economic policies (Schirm 2018b, p. 307). Value-based ideas (hereinafter "ideas"), in turn, are considered to be more path-dependent and fundamental (Schirm 2018b, p. 308). Hence, they change less quickly than interests. Ideas and interests do not necessarily serve as exclusive driving forces, but are rather seen as analytically prior to other potential factors contributing to the formation of specific governmental preferences (Schirm 2018a, p. 64).

3 The regulatory institutions will not be considered in this paper, since material interests and value-based ideas seem better suited to explain the formation of governmental preference towards Eurozone accession in Poland. For the analysis of the role of value-based ideas, material interests and regulatory institutions in shaping governmental preference formation, see Schirm, 2016. 
Although monetary policy has long been considered technocratic (that is to say a policy in which the ordinary citizens are disinterested), this has changed with the foundation of the Eurozone and subsequent outbreak of its crisis in 2009. This is because the consequences of decisions on its management have become much more visible and politicised (Copelovitch, Frieden and Walter, 2016, p. 22). The Eurozone crisis made the redistributive consequences of monetary integration visible. This resulted in the increased awareness of citizens about the interdependence of European economies and the role that supranational institutions play in determining the future of national economies (Hobolt and Wratil, 2015, p. 238). The issue of Eurozone accession, thusly, makes national governments face the challenge of resolving the dilemma between preserving national autonomy and democratic accountability and guaranteeing financial and economic stability (Rodrik, 2011).

The societal approach is chosen to explain the Polish governmental position regarding the accession to the Eurozone because the question of monetary integration affects both material interests and value-based ideas. In this paper, interests are defined as economic considerations of industries dependent on investments and trade with Eurozone countries.

Ideas, in turn, are defined as value-based collective expectations regarding the appropriate governmental policy on transferring national authorities abroad. It is claimed here that ideas, expressed by domestic electorate, and interests, expressed by domestic business lobby groups, play a determinant role in shaping the preferences of the Polish government towards Eurozone accession.

Most importantly, the societal approach specifies the conditions for either ideas' or interests' individual bearing on governmental preferences. Schirm (2018a, p. 65) argues that ideas will prevail in informing governmental preferences if the issue at stake raises fundamental concerns of voters on the appropriate role of the government when steering the economy and does not directly affect specific economic sectors' cost-benefit calculations. Interests in turn will dominate in shaping governmental positions if the issue at stake involves the cost-benefit calculations of directly affected economic sectors. If both fundamental concerns of voters and cost-benefit calculations of specific economic sector are raised by the issue at stake, both variables are expected to either reinforce or contradict each other in shaping governmental preferences (Schirm 2018a, p. 66).

\section{Hypotheses}

This paper analyses Polish governmental preference on the issue of Eurozone accession as the dependent variable and domestic ideas and interests as the explanatory variables. If a correlation between the governmental stance and respective ideas and interests is observed, then the societal approach seems plausible in explaining Polish governmental preference regarding Eurozone accession. Thus, this paper's primary hypothesis is:

H1: If ideas and/or interests oppose Poland's monetary integration, then the government will postpone the accession to the Eurozone.

Moreover, as prescribed by the societal approach, conditions for the prevalence of either ideas or interests in shaping governmental preference should be contextualised. For this purpose, the following hypotheses are provided in order to be tested: 
H2: If the issue of Eurozone accession directly affects the cost-benefit calculations of a specific well-organised ${ }^{4}$ economic sector and does not raise fundamental concerns of voters on the appropriate governmental policy on transferring national authorities abroad, then interests will prevail over ideas in shaping the governmental position due to strong lobbying.

H3: If the issue of Eurozone accession raises fundamental concerns of voters on the appropriate governmental policy on transferring national authorities abroad, and specific sectoral cost-benefit calculations are affected diffusely, then ideas will prevail over interests in shaping the governmental position.

H4: If both the cost-benefit calculations of a specific, directly affected, well-organised economic sector and fundamental concerns of voters on the appropriate governmental policy on transferring national authorities abroad are raised by the issue of Eurozone accession, then ideas will neutralise interests, given the opposing demands of the two explanatory variables.

\section{Operationalization}

The analysis of independent (domestic ideas and interests) and dependent (governmental preference) variables within this paper proceeds through the application of two primary qualitative methods: 1) the analysis of public opinion polls and 2) discourse analysis. The above methods are complemented by the analysis of the official trade and investments statistical data provided by the World Bank and the National Bank of Poland as well as secondary literature.

The analysis of public opinion polls conducted by the European Values Study (EVS) allows the value-based ideas to be distinguished. These polls are not issue specific. The data provided by EVS identifies the role voters ascribe to the government in transferring national authorities abroad. The ideas relevant to monetary integration could be found in the public attitudes on risks attached to the loss of monetary independence. Particularly, expectations of whether the government should compensate the potential costs attached to monetary integration or whether people have to bear such costs themselves will be compared. If voters consider the government responsible for compensating the potential losers of monetary integration, then they will be more willing to support transferring monetary independence abroad. If, on the other hand, people expect to bear the costs of monetary integration themselves, then they will favour the preservation of monetary policy within the jurisdiction of national government. Exemplary for such ideas are public opinion polls' questions on whether the "state should make income equal" and the "government should tax the rich and subsidise the poor" (EVS, 2017).

The examination of issue-specific public opinion polls, in turn, serves as a controlling instrument for the establishment of the presence or absence of fundamental societal concerns on transferring national authorities abroad within the issue of Eurozone accession. Issue-specific opinion polls are provided by Eurobarometer (2012, 2014, 2015, 2017, 2018). Public attitudes on whether the changeover to the euro will increase prices (Eurobarome-

4 Well-organised economic sector - a sector that possesses political (representation) and economic (generation of profits and jobs) strength (Schirm 2011, p. 50). 
ter 2014, p. 73), on favourability of EMU (Eurobarometer 2015, p. 26; Eurobarometer 2018, p. 30) and on the expectations related to the adoption of the euro (Eurobarometer 2017, p. 24) will be analysed.

The method of discourse analysis is applied for two reasons. First, the analysis of business discourse (i.e. of interest groups' statements) allows relevant material interests to be determined. Second, the presence of the relevant societal ideas and interests within the process of the formation of governmental preferences on the issue of Eurozone accession is determined by the analysis of governmental discourse.

Interest group discourse is taken from statements and publications issued by the business associations representing the industries to be affected by the issue of Eurozone accession. Concerning the procedure for the identification of the industries affected by the issue of Eurozone accession, it is necessary to identify Poland's export partners. This will determine the share of Eurozone countries as destinations for the Polish total exports and, thereby, will serve as an indicator on the motivation of industries involved in exports for lobbying on the issue of Eurozone accession.

In order to justify taking the export volume as an appropriate level of analysis of material interests, it is necessary to consider the exports-to-GDP ratio. If exports account for a substantial share of GDP in Poland, then industries engaged in exports generate considerable amount of profits and jobs and are able to influence governmental preferences. The empirical analysis of material interests, therefore, focuses on Poland's export sector, which incorporates all industries that are dependent on investments and trade with Eurozone countries.

Governmental rhetoric, in turn, is discerned from the statements made by the representatives of a ruling government (e.g. head of government, head of state, finance minister). Regardless of whether a government is considered Euro-enthusiastic or Eurosceptic, under the societal approach its representatives are interested to remain in office and, consequently, will express their positions in accordance with the principles acceptable to societal actors (Schirm 2013, p. 693). Thus, focusing on the statements from the representatives of the ruling Polish government, the connection between the societal demands and governmental preference towards Eurozone accession is illustrated. The procedure indicating the presence of the independent variables within governmental preference formation lies in setting a contextual correlation between ideational collective demands or claims expressed by affected interest groups and statements made by governmental representatives.

\section{Case study}

Despite the official obligation to join the Eurozone at some point in time, the Polish government repeatedly delays the accession. There is insufficient voting in Polish parliament to approve constitutional changes that would put the European Central Bank in charge of monetary policy over the National Bank of Poland.

\section{Ideas}

Poland represents an exceptional trend in terms of attitudes towards European integration. Poles tend to express support for the EU (CBOS 2014), but, at the same time, they 
remain sceptical towards some lines of integration, namely towards the EMU (Eurobarometer 2015, p. 26).

Over 80 percent of Poles support its country being an EU member state (CBOS 2014). In addition, the majority of Poles have trust towards the EU as a project. Forty percent of Poles perceive the EU image to be positive, while only 10 percent perceive it as negative. A considerably higher proportion of Poles than Europeans on average thought that the EU is moving in the right direction (38 percent versus 22 percent, respectively) (Eurobarometer 2012 pp. 41, 75, 77). Debomy (2018) claims that the support for accession to the EU among Poles was motivated by their expectations to gradually catch up with the standard of living enjoyed by Western Europeans, as well as the prospect of enjoying the EU's fundamental rights and freedoms (e.g. freedom of movement and establishment). Yet, while the process of continued economic integration of Poland appeared to be successful for certain sectors, it clearly failed to lift the standard of living of the whole population. Instead, the income disparities between those who participate in the export-oriented industries and those who are excluded or who have to bear the costs of economic integration arose (Bohle and Greskovits 2006, pp. 20-21). The outbreak of the Eurozone crisis, in turn, resulted into the increased awareness of citizens about the interdependence of European economies and the role that supranational institutions play in determining the future of national economies (Hobolt and Wratil 2015, p. 238). Consequently, these developments made Poles more hesitant towards the transfer of their government's monetary authority abroad.

Figure 1. Do you think the introduction of the euro would have positive or negative consequences for our country?

\section{POLAND}

-Total 'Positive consequences' $\quad \longrightarrow$-Total 'Negative consequences'

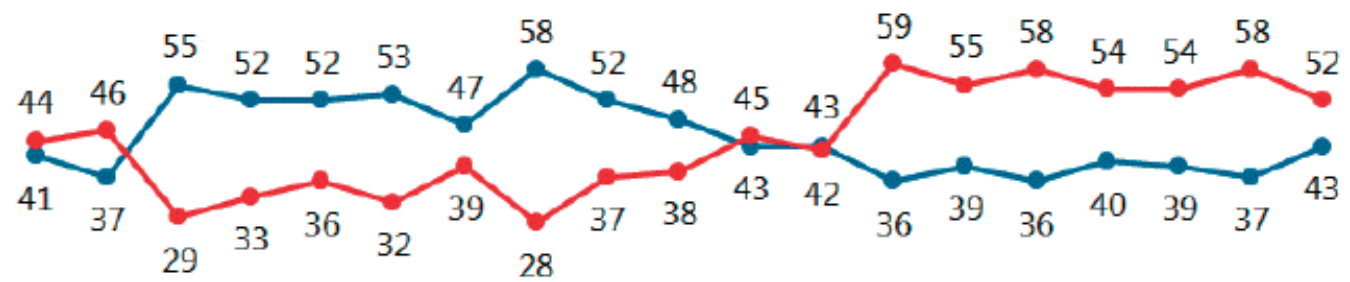

蒠

Source: Eurobarometer (2017, p. 24)

The results of the public opinion polls by EVS (2017) confirm that Poles do not seem to permit their government a responsibility for compensating the potential losers of monetary integration. It means that they expect to bear the potential costs of monetary integration themselves. Thus, less than half of Poles ( 45 percent) attach the governmental task of taxing the rich and subsidizing the poor to the important characteristics of democracy 
(EVS 2017, Q39A). In turn, the majority of Poles (57 percent) do not consider the government's responsibility to make people's incomes equal to be an important characteristic of democracy (EVS 2017, Q39G). Therefore, Poles seem to favour the preservation of monetary policy within the jurisdiction of their national government.

The examination of opinion polls specific to the issue of Eurozone accession confirms that with the eruption of the Eurozone crisis, Poles became less likely to think that the introduction of the euro would have positive consequences for their country (see Figure 1).

A vast majority of Poles (76 percent) believed that the introduction of the euro would increase prices (Eurobarometer 2014, p. 73) and only less than a third of Poles supported the accession to the Eurozone (Eurobarometer 2015, p. 26). Only one out of ten Poles expressed readiness to join the Eurozone as soon as possible while half of respondents would prefer the accession to be as late as possible, or never (Eurobarometer 2018, p. 30). It is remarkable that only 19 percent of Poles were aware that their country was committed to Eurozone accession (Eurobarometer, 2014, p. 7).

\section{Interests}

Poland's goods exports-to-GDP ratio indicates that its economy is export oriented (World Bank 2019a). It means that the sectors engaged in exports generate a considerable amount of profits and jobs and, following the analytical framework presented in this paper, are able to influence governmental preferences formation. This can justify the taking of export volume as an appropriate level of examination of material interests expected to be affected by the issue of Eurozone accession.

The identification of Poland's export partners, in turn, helps determine the share of Eurozone countries as destinations for Poland's total export of goods and serves as an indicator for the motivations to lobby for accession to the Eurozone by industries involved in exports. Table 2 illustrates that Germany is Poland's most important export partner, which between 2007 and 2017 accounted for over a quarter of its total export on average. France, Italy and the Netherlands are other important destinations for Polish exports representing the Eurozone. Hence, over half (56 percent on average) of Poland's total export of goods accounts for Eurozone countries (see Table 2).

The variety of Polish exports (i.e. the number of different brands) to the Eurozone is as high as that of the Czech Republic and substantially exceeds a respective variety of other Central and Eastern European Countries (CEECs) (Belka 2013, p. 20). Moreover, Poland is deeply integrated into the Eurozone's supply chains and production networks, and it annually increases its share (Rozworski, 2015). Due to the Polish-German cooperation, vehicles and vehicle parts remain among Poland's leading export commodities - of which a substantial share is sold under the German brands, i.e. "up to 40 percent of Poland's exports to Germany end up as German exports to the rest of the world" (Reszczynski 2014, p. 28). In addition, 83 percent of the stock of Poland's inward FDI accounts for the Eurozone with Dutch, German, Luxemburgish and French firms leading inward investment activity (Belka 2013, p. 24; Bank of Poland, 2014). The inflow of foreign capital has made Poland's exports more innovative and technologically advanced. This has forced Poland to double its export of high-tech production (MFA of Poland 2014, pp. 82-83).

The Polish export sector would substantially benefit from abandoning transaction costs which possess obstacles to substantial economic gains. Therefore, it is strongly interest- 
ed in the accession of Poland to the Eurozone, as confirmed by the survey of 230 Polish companies engaged in the exports of goods and services. Fifty-two percent of companies responded that the adoption of the euro in Poland would increase their competitiveness (Gorynia, et al. 2012, p. 27).

Table 2. Poland's top Export Partner Share (in \%)

\begin{tabular}{|l|c|c|c|c|c|c|c|c|c|c|c|}
\hline Partner Name & $\mathbf{2 0 0 7}$ & $\mathbf{2 0 0 8}$ & $\mathbf{2 0 0 9}$ & $\mathbf{2 0 1 0}$ & $\mathbf{2 0 1 1}$ & $\mathbf{2 0 1 2}$ & $\mathbf{2 0 1 3}$ & $\mathbf{2 0 1 4}$ & $\mathbf{2 0 1 5}$ & $\mathbf{2 0 1 6}$ & $\mathbf{2 0 1 7}$ \\
\hline EU & 78.8 & $\mathbf{7 7 . 9}$ & $\mathbf{7 9 . 6}$ & $\mathbf{7 8 . 9}$ & $\mathbf{7 7 . 7}$ & $\mathbf{7 5 . 2}$ & 74.7 & 76.6 & 78.8 & 78.9 & 79.0 \\
\hline Eurozone & 57.3 & 56.5 & 58.4 & 57.3 & 56.0 & 53.7 & 52.9 & 54.7 & 56.1 & 56.0 & 56.5 \\
\hline Germany & 25.9 & 25.1 & 26.1 & 26.0 & 26.0 & 24.9 & 25.0 & 25.9 & 26.9 & 27.0 & 27.2 \\
\hline United Kingdom & 5.9 & 5.8 & 6.4 & 6.3 & 6.5 & 6.8 & 6.5 & 6.4 & 6.8 & 6.6 & 6.4 \\
\hline Czech Republic & 5.5 & 5.7 & 5.9 & 5.9 & 6.2 & 6.2 & 6.1 & 6.3 & 6.5 & 6.5 & 6.3 \\
\hline France & 6.1 & 6.2 & 7.0 & 6.8 & 6.1 & 5.8 & 5.6 & 5.6 & 5.6 & 5.5 & 5.6 \\
\hline Italy & 6.6 & 6.0 & 6.8 & 6.0 & 5.4 & 4.9 & 4.3 & 4.5 & 4.8 & 4.8 & 4.9 \\
\hline $\begin{array}{l}\text { Russian Feder- } \\
\text { ation }\end{array}$ & 4.6 & 5.2 & 3.7 & 4.2 & 4.5 & 5.5 & 5.3 & 4.4 & 2.9 & 2.9 & 3.1 \\
\hline Netherlands & 3.8 & 4.0 & 4.2 & 4.4 & 4.4 & 4.4 & 4.0 & 4.1 & 4.4 & 4.4 & 4.3 \\
\hline Sweden & 3.2 & 3.2 & 2.7 & 3.0 & 2.9 & 2.6 & 2.7 & 2.8 & 2.7 & 2.9 & 2.7 \\
\hline Hungary & 2.9 & 2.8 & 2.7 & 2.8 & 2.6 & 2.4 & 2.5 & 2.6 & 2.7 & 2.6 & 2.6 \\
\hline Ukraine & 4.0 & 3.7 & 2.5 & 2.5 & 2.5 & 2.9 & 2.8 & 2.0 & 1.7 & 2.0 & 2.2 \\
\hline
\end{tabular}

Source: World Bank (2019b)

In turn, leaders of the Polish business community appealed to Prime Minister Mateusz Morawiecki in an open letter, requesting to start preparations for Poland's Eurozone accession:

With more than 50\% share of the countries of the single currency in Polish exports, we are one highly integrated and synchronised economy. And that means that the policy of the European Central Bank will be adapted to the needs of our country. [...] At our transit geographical location, we have no choice. [...] We believe that it is necessary to set up a permanent council that will identify the necessary changes in the legal and financial system, help select the right moment to enter the ERM II mechanism and profitable zloty exchange rate for the Polish economy, and initiate a social information campaign that will provide the public with objective data on the common currency and dispel myths about euro adoption. (Rzeczpospolita, 2018)

The Confederation of Polish Employers, Lewiatan, the most influential business organisation in Poland (associating 3,900 companies that employ 835,000 workers), stated that the elimination of currency exchange operations after Poland's accession to the Eurozone would remove foreign exchange risks and substantially cut down business expenses, which would make Poland's economy more competitive. Another significant benefit of Poland's Eurozone integration would be the removal of preconditions for a currency 
crisis, said Lewiatan (2016). This benefit is of an additional importance for Poland, because the weakening of the Polish zloty and its volatility substantially increases the risks involved in business activities. Lewiatan therefore stressed the necessity for parliament to ratify the amendments to the constitution needed for Poland's accession to the Eurozone. "If there is no political will to bring Poland into the Eurozone this will be synonymous with intentionally exposing the Polish economy to a very high risk," said Lewiatan representatives in a statement (Warsaw voice, 2008).

To sum up, the strong trade connectedness of Poland with Eurozone countries and FDI stock and inflows into Poland from Eurozone countries provided Poland's export sector with strong incentives for lobbying in favour of Poland's accession to the Eurozone. This is because accession to the Eurozone would remove foreign exchange risks and substantially increase the competitiveness of export-involved industries.

\section{Governmental preference}

There have been two mainstream political parties in Poland since its accession to the EU: Law and Justice (PiS) and Civic Platform (PO). After it won the parliamentary elections of 2007 and its leader, Donald Tusk, took over the prime ministerial office, PO declared that Poland would head into Eurozone integration. Tusk insisted on both the political and economic urgency for Poland to adopt the euro and announced for the year 2012 to become the target date for Poland's accession to the Eurozone (Dandashly and Verdun, 2010, p. 21). "It should be emphasised that the single currency is now a key part of European integration. Staying outside the common currency, as a strategy, would be dangerous for Poland," stated Tusk (Radio Poland, 2013). Tusk's government ambitions regarding Poland's early Eurozone accession were severely criticised by PiS, the opposition. PiS leader Jaroslaw Kaczynski accused Polish authorities of "selling the country's sovereignty [...] for the sake of private interests" (IHS Global Insight, 2011).

Prime Minister Tusk initiated public discussion but was not successful in convincing voters in the rationality behind introducing the euro into Poland. Therefore, he gave up his ambitious plans for Poland's accession to the Eurozone in 2012 and made no effort to mention any probable date for the adoption of the euro (The Wall Street Journal, 2014). "Poland should not join the Eurozone if significant doubts exist as to how this will affect the lives of every Pole," stated Tusk (Xinhua, 2010). "The decision on Poland's entry to the Eurozone will be made only when it will be certain that taking on the euro will not lead to any losses for Poles," added Tusk (Intellinews, 2013).

In an attempt to reverse negative opinions on Eurozone accession, the Cabinet of Tusk resorted to promoting the potential benefits of integration into the Eurozone. However, as opinion polls proved, this effort did not contribute to the rise of enthusiasm for the euro adoption among Poles. On the contrary, such attempts led to the rise in popularity of PO's major political rival-PiS, known for its nationalist orientation and leaning towards Euroscepticism (Heinisch and Landsberger, 2012, p. 15). PiS leader Jaroslaw Kaczynski insisted on the necessity to increase the share of the Polish state and Polish investors in core economic sectors and advocated the preservation of the zloty in the capacity of Poland's national currency (Tokarski and Wiklund, 2013). He also called the euro a "German-dominated instrument of economic oppression" (Cienski, 2018). "The euro is completely contrary to our interests," Kaczynski said (Radio Poland, 2011) in his anti-euro 
adoption public speech, who also claimed that Eurozone integration would undermine Poland's sovereignty In addition, Kaczynski opposed the fiscal compact treaty, which provides the EU with more competences towards the control of national budgets (Stratfor, 2013). In short, taking the approach to defend Polish monetary independence allowed PiS win support by a significant quantity of voters (The Guardian, 2015; The Polish Politics Blog, 2015).

After coming to power, Kaczynski stated: "The Eurozone brings benefits to the strongest countries in the EU, at the expense of economically weaker EU member states". He suggested that Poland's accession to the Eurozone would cause high inflation and that his country's monetary integration is possible only "when earnings in Poland would be comparable to earnings in 'old' EU member states” (Polish News Bulletin 2019).

In the 2015 parliamentary election manifesto, Beata Szydlo, the Law and Justice candidate for Prime Minister, stated: "I can declare today that if Law and Justice wins the elections and forms the next government, one of my first decisions would be to abolish the government's plenipotentiary tasked with introducing the euro in Poland" (Open Europe, 2015). Subsequently, when she became Prime Minister, Szydlo said: "People feel more and more that the elites in Brussels are... no longer in touch with the problems that they should be concerned about - such as increasing employment and improving wages [...] This leads to crisis" (Financial Times, 2017).

The issue of the euro adoption had also become central in the political debates ahead of the presidential elections in 2015. Thus, Andrzej Duda, the presidential candidate, conducted his campaign with the slogan "Yes to Europe, No to the Euro". Remarkably, putting the euro issue at the centre of his presidential campaign allowed Duda to win the election (Bloomberg, 2015). Later on, Krzysztof Szczerski, Presidents Duda's senior adviser, suggested a referendum on Eurozone accession to be held in Poland. He stated: "The decision on ceasing to mint one's own currency must be [...] the nation's decision" (The Telegraph, 2015). It is worth mentioning, however, that Poland is not legally required to hold a referendum on the issue of the Eurozone accession.

Mateusz Morawiecki, who replaced Beata Szydlo on the post of prime minister, while addressing monetary integration, said:

In today's Europe, it is precisely the struggle of interests that plays a pivotal role and we can see exactly this struggle and want to use our national sovereignty and tradition as an advantage in the fight for our national interests (Morawiecki, 2017).

He also criticised the European project of ever-closer integration. "I'm for a Europe of nation states, [...] a United States of Europe won't get anywhere because people won't accept it," stated Morawiecki (2017). To sum up, Polish authorities have shown demonstratively that they-in line with societal ideas - oppose Poland's monetary integration.

\section{Conclusion}

This paper has argued that explaining the position of the Polish government towards Eurozone accession requires an analysis of material considerations of industries dependent on investments and trade with the Eurozone countries, as well as ideational collective expectations regarding the appropriate governmental policy on transferring national au- 
thorities abroad. For this purpose, the societal approach to governmental preference formation has been employed. It analyses the impact of domestic value-based ideas and material interests on governmental positions in international relations and asks under which conditions would either ideas or interests prevail in shaping the governmental preference. Following the societal approach to governmental preference formation, the puzzle of why Poland did not join the Eurozone despite being dependent on investments and trade with Eurozone countries has been explained. The societal approach was chosen because neither institutionalist nor neofunctionalist arguments suffice to solve the above puzzle.

As shown in this research, Poland's strong dependence on exports to and foreign direct investments from Eurozone countries provide its export sector with a strong motivation for lobbying with the aim to positively influence governmental preference in favour of Eurozone accession. In turn, Polish voters do not seem to ascribe their government a responsibility for compensating the potential losers of monetary integration. It means that they expect to bear the costs of potential Eurozone accession themselves. Therefore, Poles favour the preservation of monetary policy within the jurisdiction of their national government. Hence, they oppose Eurozone accession.

It was demonstrated that the issue of Eurozone accession in Poland raises both the cost-benefit calculations of the export sector and fundamental concerns of voters on the appropriate governmental policy on transferring national authorities abroad. Following societal ideas, the Polish government refused to pursue monetary integration and subsequent Eurozone accession. Thus, ideational societal expectations have neutralised material interest groups' considerations in bearing on the Polish governmental preference towards Eurozone accession. These points support the first (H1) and the fourth (H4) hypotheses of this study and explain why Poland did not join the Eurozone.

\section{References}

Bank of Poland. (2014). Foreign Direct Investment in Poland. Retrieved from National Bank of Poland: http://www.nbp.pl/homen.aspx?f=/en/publikacje/ziben/ziben.html

Beblavy, M. (2007). Issues and problems related to Eurozone entry of the new accession countries : an analytical review. In: D. Cobham, The Travails of the Eurozone (pp. 271292). London: Palgrave Macmillan. doi:https://doi.org/10.1057/9780230801479_11

Belka, M. (2013). How Poland's EU Membership Helped Transform its Economy. Retrieved from Group of Thirty: http://group30.org/images/uploads/publications/G30_HowPolandEUMembershipTransformEconomy.pdf

Bloomberg. (2015). Euro Debate Ignites in East EU in Face of Public Skepticism. Retrieved from Bloomberg-Business : http://www.bloomberg.com/news/articles/2015-04-01/euro-debate-reignites-in-eu-s-east-in-face-of-public-skepticism

Bohle, D., Greskovits, B. (2006). "Capitalism without Compromise: Strong Business and Weak Labor in Eastern Europe's New Transnational Industries." Studies in Comparative International Development, 41 (1): 3-25.

CBOS. (2014). NARASTANIE OBAW ZWIAZZANYCH Z WPROWADZENIEM EURO. Retrieved from CBOS: http://cbos.pl/SPISKOM.POL/2014/K_151_14.PDF

Cienski, J. (2018). Euro push in Poland pitched as peace offering with EU. Retrieved from Politico: https://www.politico.eu/article/the-case-for-poland-to-join-the-euro/ 
Copelovitch, M., Frieden, J., Walter, S. (2016). The Political Economy of the Euro Crisis. Comparative Political Studies, 1-30. HYPERLINK "https://doi. org/10.1177/0010414016633227” https://doi.org/10.1177/0010414016633227

Dandashly, A., Verdun, A. (2010). The Slow Trip to the East: The Domestic Politics of Euro Adoption in the Czech Republic, Hungary and Poland. Retrieved from Fifth Pan European Conference organized by the ECPR Standing Group on European Union Politics, June 23-26: http://www.jhubc.it/ecpr-porto/virtualpaperroom/141.pdf

Debomy, D. (2018). They Love Me, They Love Me Not, They Love Me a Little. Retrieved from Jacques Delors Institute: https:/institutdelors.eu/wp-content/uploads/2018/04/ PublicOpinionsVisegradCountries-Debomy-April18.pdf

EC. (2016). Convergence Report. Retrieved from European Commission: https://ec.europa. eu/info/sites/info/files/file_import/ip026_en_2.pdf

EC. (2018). Convergence criteria for joining. Retrieved from European Commission: https://ec.europa.eu/info/business-economy-euro/euro-area/enlargement-euro-area/ convergence-criteria-joining_en

ECB. (2016). Convergence Report. Retrieved from European Central Bank: https://www. ecb.europa.eu/pub/pdf/conrep/cr201606.en.pdf

Eurobarometer. (2012). Standard Eurobarometer 78. Public opinion in the European Union. Retrieved from European Commission: http://ec.europa.eu/commfrontoffice/publicopinion/index.cfm/ResultDoc/download/DocumentKy/63169

Eurobarometer. (2014). Introduction of the euro in the more recently acceded member states. Flash Eurobarometer 400. HYPERLINK "https://ec.europa.eu/commfrontoffice/publicopinion/index.cfm/ResultDoc/download/DocumentKy/61126” https:/ec.europa.eu/ commfrontoffice/publicopinion/index.cfm/ResultDoc/download/DocumentKy/61126

Eurobarometer. (2015). Standard Eurobarometer 83. Public opinion in the European Union (First results). Retrieved from European Commission: http://ec.europa.eu/public_opinion/archives/eb/eb83/eb83_first_en.pdf

Eurobarometer. (2017). Introduction of the euro in the Member States that have not yet adopted the common currency. Flash Eurobarometer 453. HYPERLINK "https://ec.europa.eu/commfrontoffice/publicopinion/index.cfm/ResultDoc/download/DocumentKy/78338” https://ec.europa.eu/commfrontoffice/publicopinion/index.cfm/ResultDoc/ download/DocumentKy/78338

Eurobarometer. (2018). Introduction of the euro in the Member States that have not yet adopted the common currency. Retrieved from European Commission: https://ec.europa.eu/commfrontoffice/publicopinion/index.cfm/ResultDoc/download/Document$\mathrm{Ky} / 82943$

EVS. (2017). European Values Study 2017: Integrated Dataset. Retrieved from European Values Study: https://zacat.gesis.org/webview/index.jsp?object=http://zacat.gesis.org/ obj/fCatalog/Catalog5

Financial Times. (2017). Polish PM hails pushback against deeper European integration. Retrieved from Financial Times: HYPERLINK "https://www.ft.com/content/05942108c55c-11e7-ald2-6786f39ef675” https://www.ft.com/content/05942108-c55c-11e7-ald26786f39ef675

Fioretos, O. (2011). Historical Institutionalism in International Relations. International Organization, 65(2), 367-399. 
Frieden, J., Rogowski, R. (1996). The Impact of the International Economy on National Policies: An Analytical Overview. In R. Keohane, H. Milner, Internationalization and Domestic Politics (pp. 25-47). New York: Cambridge University Press.

Goldstein, J., Keohane, R. O. (1993). Ideas and Foreign Policy: An Analytical Framework. In J. Goldstein, R. O. Keohane, Ideas and Foreign Policy: Beliefs, Institutions, and Political Change (pp. 3-30). Ithaca and London: Cornell University Press.

Gorynia, M., Jankowska, B., Pietrzykowski, M., Tarka, P., Dzikowska, M. (2012). Poland's entry into the eurozone and the international competitiveness and internationalisation of Polish companies . Retrieved from Poznan University of Economics: http://old. ue.poznan.pl/att/DZIEK_GM/working_papers/Working_Paper_No3_2012.pdf

Guardian. (2015). Andrzej Duda victory in Polish presidential election signals shift to right. Retrieved from The Guardian: http://www.theguardian.com/world/2015/may/25/andrzej-duda-victory-polish-presidential-election

Hall, P. A., Soskice, D. (2001). An Introduction to Varieties of Capitalism. In P. A. Hall, D. Soskice, Varieties of Capitalism. The Institutional Foundations of Comparative Advantages (pp. 1-68). Oxford: Oxford University Press.

Heinisch, R., Landsberger, C. (2012). 'Returning to Europe' - East Central Europe's Complex Relationship with European Integration and its Repercussions. Retrieved from https:// www.uni-salzburg.at/fileadmin/multimedia/Politikwissenschaft\%20und\%20Soziologie/documents/Heinisch-Landsberger_East_Central_Europe\%E2\%80\%99s_Complex_Relationship_with_European_Integration.pdf

Hobolt, S. B., Wratil, C. (2015). Public opinion and the crisis: the dynamics of support for the euro. Journal of European Public Policy, 22(2): 238-256. doi: 10.1080/13501763.2014.994022.

IHS Global Insight. (2011). Polish Opposition Calls Against Deeper European Integration. Retrieved from IHS Global Insight: https://www.nexis.com/results/enhdocview.do?docLinkInd=true\&ersKey=23_T23667800642\&format $=$ GNBFI\&startDocNo $=0 \&$ resultsUrlKey=0_T23667800644\&backKey $=20 \_T 23667800645 \& \mathrm{csi}=250053 \& \mathrm{docNo}=1$

IMF. (2015). Central and Eastern Europe: new member states policy forum 2014. Retrieved from IMF: http://www.imf.org/external/pubs/ft/scr/2015/cr1598.pdf

Intellinews. (2013). PM: Decision on euro adoption only when it is certainly harmless for Poland. Retrieved from: HYPERLINK "https://advance.lexis.com/api/document?collection=news\&id=urn:contentItem:57RT-X811-F15C-J0J3-00000-00\&context=1516831" https://advance.lexis.com/api/document?collection=news\&id=urn:contentItem:57RTX811-F15C-J0J3-00000-00\&context $=1516831$.

Johnson, J. (2008). The remains of conditionality: the faltering enlargement of the euro zone. Journal of European Public Policy, 15(6), 826-841. Retrieved from http://www. tandfonline.com/doi/abs/10.1080/13501760802196564

Lewiatan. (2016). Polish Confederation Lewiatan. Retrieved from Lewiatan: http://konfederacjalewiatan.pl/en/about-us

MFA of Poland. (2014). Poland's 10 years in the European Union. Retrieved from Ministry of Foreign Affairs of Poland: https://www.msz.gov.pl/resource/fa393546-1309-4ea8ad30-2c93d01e7f36:JCR

Moravcsik, A. (1997). Taking Preferences Seriously: A Liberal Theory of International Politics . International Organization, 51(4), 513-553. 
Morawiecki, M. (2017). Policy statement by Prime Minister Mateusz Morawiecki-stenographic record. Retrieved from The Chancellery of the Prime Minister: https://www. premier.gov.pl/en/policy-statement-by-prime-minister-mateusz-morawiecki-stenographic-record.html

Open Europe. (2015). Greek crisis could see euro membership emerge as key issue in the Polish election campaign. Retrieved from Open Europe: http://openeurope.org.uk/today/ blog/greek-crisis-could-see-euro-membership-emerging-as-key-issue-in-polish-election-campaign/

Polish News Bulletin. (2019). Myths and Truth About Euro. Retrieved from: HYPERLINK "https://advance.lexis.com/api/document?collection=news\&id=urn:contentItem:5VX9-XMM1-DYWS-R001-00000-00\&context=1516831" https://advance. lexis.com/api/document?collection=news\&id=urn:contentItem:5VX9-XMM1-DYWS-R001-00000-00\&context $=1516831$

Polish Politics Blog. (2015). Analysis of the contemporary Polish political scene. Retrieved from THE POLISH POLITICS BLOG: https://polishpoliticsblog.wordpress.com/

Radio Poland. (2011). 'Adopting euro against Poland's interests' says opposition leader. Retrieved from Radio Poland: http://www.thenews.pl/1/12/Artykul/59135,Adopting-euro-against-Polands-interests-says-opposition-leader

Radio Poland. (2013). Polish governmentrefuses to set date for eurozone entry. Retrieved from Radio Poland: HYPERLINK "http://archiwum.thenews.pl/1/12/Artykul/128363,Polish-government-refuses-to-set-date-for-eurozone-entry" http://archiwum.thenews. pl/1/12/Artykul/128363,Polish-government-refuses-to-set-date-for-eurozone-entry

Reszczynski, C. (2014). Poland and the Eurozone: Prospects for and Challenges to Accession. Retrieved from http://auislandora.wrlc.org/islandora/object/auislandora\%3A10039/datastream/PDF/view

Riedel, R. (2015). Czechs' and Slovaks' Approaches to the Eurozone Two Decades after the Czechoslovakian Divorce. Yearbook of Polish European Studies, 18, 193-210. Retrieved from http://www.ce.uw.edu.pl/pliki/pw/18-2015_riedel.pdf

Rodrik, D. (2011). The globalization paradox: Democracy and the future of the world economy. New York, NY: W.W. Norton.

Rozworski, M. (2015). Poland's Iron Consensus. Retrieved from https://www.jacobinmag. com/2015/11/poland-october-elections-kaczynski-law-justice-party/

Rzeczpospolita. (2018). Przyjęcie euro-list otwarty. Premierze Morawiecki, już czas na euro. Retrieved from Rzeczpospolita: https://www.rp.pl/Finanse/301019939-Przyjecieeuro---list-otwarty-Premierze-Morawiecki-juz-czas-na-euro.html

Schirm, S. A. (2011). Varieties of Strategies: Societal Influences on British and German Responses to the Global Economic Crisis. Journal of Contemporary European Studies, 19(1), 47-62.

Schirm, S. A. (2013). Global politics are domestic politics: a societal approach to divergence in the G20. Review of International Studies, 39(3), 685-706. Retrieved from http:// journals.cambridge.org/abstract_S0260210512000216

Schirm, S. A. (2016). Domestic ideas, institutions, or interests? Explaining governmental preferences towards global economic governance. International Political Science Review, 37(1), 66-80.

Schirm, S. A. (2018a). Societal foundations of governmental preference formation in the Eurozone crisis. European Politics and Society, 19(1), 63-78. 
Schirm, S. A. (2018b). The Domestic Politics of European Preferences Towards Global Economic Governance. New Global Studies, 12(3), 303-324.

Stratfor. (2013). Poland: An EU Success Story Hits Troubled Times. Retrieved from Stratfor: https://www.stratfor.com/analysis/poland-eu-success-story-hits-troubled-times

Telegraph. (2015). Poland should join euro only after referendum, says president-elect's adviser. Retrieved from The Telegraph: http://www.telegraph.co.uk/news/worldnews/ europe/poland/11723365/Poland-should-join-euro-only-after-referendum-says-president-elects-adviser.html

Tokarski, P., Wiklund, E. (2013). 10 Years after Swedish Euro "Nej": Lessons for Poland. Retrieved from The Polish Institute of International Affairs: http://www.pism.pl/files/?id_ plik $=14458$

Wall Street Journal. (2014). Polish Leaders Hope Debate Can Change Perception of Euro. Retrieved from The Wall Street Journal: http://www.wsj.com/articles/polish-leadershope-debate-can-change-perception-of-euro-1412951831

Warsaw voice. (2008). Gov't Approves 'Road Map' to Euro-zone. Retrieved from The Warsaw voice online: http://www.warsawvoice.pl/WVpage/pages/articlePrint.php/19080/ article

World Bank. (2019a). Exports By Country and Region. Retrieved from World Integrated Trade Solution: HYPERLINK "https://wits.worldbank.org/CountryProfile/en/Country/POL/StartYear/2007/EndYear/2017/TradeFlow/Export/Partner/ALL/Indicator/ XPRT-TRD-VL" https://wits.worldbank.org/CountryProfile/en/Country/POL/StartYear/2007/EndYear/2017/TradeFlow/Export/Partner/ALL/Indicator/XPRT-TRD-VL

World Bank. (2019b). Export Partner Share. Retrieved from World Integrated Trade Solution: HYPERLINK "https://wits.worldbank.org/CountryProfile/en/Country/POL/ StartYear/2007/EndYear/2017/TradeFlow/Export/Partner/BY-COUNTRY/Indicator/ XPRT-PRTNR-SHR” https://wits.worldbank.org/CountryProfile/en/Country/POL/ StartYear/2007/EndYear/2017/TradeFlow/Export/Partner/BY-COUNTRY/Indicator/ XPRT-PRTNR-SHR

Xinhua. (2010). Euro adoption not a priority for Poland: PM. Retrieved from Xinhua General News Service: "https://advance.lexis.com/api/document?collection=news\&id=urn:contentItem:7YDK-7H50-Y958-C067-00000-00\&context=1516831” https:// advance.lexis.com/api/document?collection=news\&id=urn:contentItem:7YDK-7H50-Y958-C067-00000-00\&context=1516831 . 